\title{
A historical perspective on the life cycle of a tourist activity: dolphin watching in Brazil's Fernando de Noronha archipelago
}

Marina Consuli Tischer 1,2,3; Alexandre Schiavetti 1,2; Flávio José de Lima Silva 3,4; José Martins da Silva-Jr 5

\begin{abstract}
In Brazil, the whale watching is practiced with different species, such as whales, dolphins, and porpoises. This activity facilitates the growth of the economic activities of communities in many regions of the country, and it may be a tool for awareness about the marine preservation and conservation. Moreover, the whale or dolphin watching also impacts native species. The Fernando de Noronha Archipelago (FN) is a worldwide watching tourism site due to the time of the development of activities and the ease to watch cetaceans, mainly the spinner dolphin (Stenella longirostris). The aim of this study was to characterize the dolphin watching in FN. Additionally, we will investigate the applicability of the "Tourism Area Life Cycle" (TALC) approach for a tourism activity, identifying the main events or stages that promoted significant changes throughout the history of the activity in the archipelago. We observed that both landbased and boat-based (boat trips) are available in FN. The boat trips are more common and involve the triple of tourists than land-based watching. However, the last provides more informative and educational component. The history of dolphin watching tourism in FN was developed concomitantly with the tourism destination of the archipelago as a whole. Through TALC analysis, dolphin watching in FN had its development together with the destination development and, currently, both areas present stagnation stage indicators. In addition, the land-based watching, for being less impacting and more educative, has potential to increase the visitation.
\end{abstract}

Keywords: Whale Watching; Spinner Dolphin; Marine Protected Areas; TALC

\footnotetext{
1 Programa de Pós-Graduação em Ecologia e Conservação da Biodiversidade - Universidade Estadual Santa Cruz, Rodovia Ilhéus-Itabuna km 16 - Salobrinho - Ilhéus (BA), CEP 45662-000, Brasil.

${ }^{2}$ Laboratório de Etnoconservação e Áreas Protegidas (LECAP) - Departamento de Ciências Agrárias e Ambientais Universidade Estadual Santa Cruz.

${ }^{3}$ Projeto Golfinho Rotador - Rua Eurico Cavalcante de Albuquerque, 05, Boldró - Fernando de Noronha (PE), CEP 53990-000, Brasil.

4 Universidade do Estado do Rio Grande do Norte, Curso de Turismo, Avenida Doutor João Medeiros Filho, 3419 - Potengi, Natal (RN), CEP 59120555, Brasil.

${ }^{5}$ Instituto Chico Mendes de Conservação da Biodiversidade - ICMBio, Fernando de Noronha (PE), Boldró, CEP 53990-000, Brasil.

* Corresponding author. E-mail address: M. C. Tischer - Tel.: +55 19998902212 marina@golfinhorotador.org.br (M. C. Tischer), aleschi@uesc.br (A. Schiavetti), flavio@golfinhorotador.org.br (F. J. L. Silva) rotador@golfinhorotador.org.br (J. M. da Silva-Júnior)
} 


\section{INTRODUCTION}

Brazil has an $8,500 \mathrm{~km}$ coastline, many estuarine systems, and hydrographic basins allowing the existence of a significant diversity of cetacean species (46 species, according to Monteiro-Filho et al., 2011). Such features promote a high potential to develop the whale watching in the country. According to a report released in the early 90's by the International Whaling Commission (IWC 1994), five remarkable locations in Brazil are used for regular cetacean watching tourism activity. Such environments provide sightings of humpback whale (Megaptera novaeangliae) in Abrolhos Marine National Park (State of Bahia); bottlenose dolphin (Tursiops truncatus) in Laguna (State of Santa Catarina); right whale (Eubalaena australis) in southern parts of the State of Santa Catarina; Guiana dolphin (Sotalia guianensis) in Anhatomirim Environmental Protection Area (APA) (State of Santa Catarina), and the spinner dolphin (Stenella longirostris) in Fernando de Noronha (FN) archipelago (State of Pernambuco). Nowadays, those are still the primary regions for watching activity in the country, adding the current watching tourism of Inia geoffrensis in Novo Airão in the Amazon Basin (State of Amazonas) (Romagnoli et al. 2011) and Guiana dolphin (Sotalia guianensis) in Pipa Beach (State of Rio Grande do Norte) (Santos-Jr. et al., 2006).

As cetacean watching tourism has developed worldwide, its sustainability has been contested (Higham et al. 2014; Silva-Jr 2017) due to its impact on animal populations (Lusseau, 2003a,b; Santos-Jr et al. 2006; Courbis and Timmel 2009; Stamation et al. 2010; Meissner et al. 2015; and others) and also in economic and social aspects, either concerning to local population offering the activity or the visitors interested in watching tourism (Orams 2000; Valentine et al. 2004; O'Connor et al. 2009; Mustika et al. 2012; Pratt and Suntikul 2015). Studies can help planning the activity, mainly those measuring short and long-term impacts on animal populations to define norms for the development and management of the whale watching (Constantine 1999; Inman 2016).

The whale watching has become one of the most important sources of income for the coastal population, as reported by Filla and Monteiro-Filho (2009) in Cananéia, southern Brazil, and for some coastal communities in Scotland (Woods-Ballard et al. 2003). This non-lethal use of cetacean leads to significant awareness about environmental issues for the tourists and coastal population (IFAW 1997) and an information tool for researchers. In this way, the whale watching may lead to increased marine preservation and conservation.

The tourism in $\mathrm{FN}$ was established due to the growing demand for contact with nature together with the unplanned tourism development and the need to conserve natural resources (Silva 2013). Understanding how an area that was previously occupied by its local population has turned into a tourism destination (sometimes attracting thousands of visitors) is a study object that helps to aim the sustainability of those destinations, which often put in danger social, cultural and environmental patrimonies of the area due to lack of management. Butler (1980) proposed one of the most used models for studying the development of tourism destination. In his model, called "Tourism Area Life Cycle" (TALC), the author identifies six stages of the tourism destinations that went or will undergo at some point: exploration, involvement, development, consolidation, 
stagnation and post-stagnation, this last stage being characterized for having three possible ways (decline, rejuvenation or stabilization), depending on the involvement of the actors interested in the continuity of the tourism activity. This model was applied in FN by Alvares and Lourenço (2009), Falcão (2010) e Zanirato and Tomazzoni (2014), who concluded that the tourism in FN went through four out of the six stages of TALC and that in 2009 the region demonstrated an overlap of the developing and consolidation indicators. Even with a detailed description of the tourism activity in $\mathrm{FN}$, these studies do not show references to dolphin watching activity. As the model is based on an overtime development, the application of life cycle indicators of a tourism destination may be useful to characterize the evolution of dolphin watching in $\mathrm{FN}$.

The cetacean watching tourism in $\mathrm{FN}$ occurs since the 70's (Silva 2013), and the region is now known as one of the best places for spinner dolphin watching (Stenella longirostris) given the ease to watch and the presence of large populations of the species. Boat-based and land-based spinner dolphin watching are possible in FN during the day. The animals use the archipelago to rest, reproduce, for parental care, and as shelter against predators (Silva-Jr. et al. 2005a). The humpback whale (Megaptera novaeangliae) is the second most common cetacean in $\mathrm{FN}$, being possible to watch the species from July to October (Lodi 1994). Other cetaceans species registered in the archipelago are the pantropical spotted dolphin (Stenella attenuata), the short-finned pilot whale (Globicephala macrorhynchus) and the bottlenose dolphin (Tursiops truncatus) (Silva-Jr. et al. 2005b).

In this way, this research aims to describe the cetacean watching tourism activities in
FN by considering development, supply, demand, and laws of the archipelago. In addition, we aim to identify the main events or stages that caused the higher impacts throughout the history of the activity in the archipelago. At the same time, we will determine the applicability of the TALC approach for a tourism activity such as the dolphin watching. This is a new approach to this method, which can contribute to a better understanding of the relationship of the development of a tourist destination and the activities and tours that are explored. We also conducted an update on the use of TALC in FN, including the last years that were not investigated in earlier studies.

\section{MATERIAL AND METHODS}

We conducted a literature review on the history of the $\mathrm{FN}$ archipelago focusing on the development of tourist activity and the registers of dolphin watching.

The number of tourists joining watching tourism activities was obtained from the Chico Mendes Institute for Biodiversity Conservation (ICMBio), federal institution manager of the marine protected areas (MPA) in the archipelago, and the Spinner Dolphin Project for demand analysis through the Pearson correlation test $(\alpha \leq 0.05)$. Documents such as Management Plans (FUNATURA/IBAMA 1990; IBAMA 2005) and Support Capacity Study of the MPA (Luís-Jr 2009; Elabore 2008) were consulted together with reports about World Heritage Sites (UNESCO 2001, 2015). A compilation of national and local laws of protection to cetaceans and watching tourism regulation was also used. Some data not found in literature or through governmental or nongovernmental institutions were obtained through informal conversations with residents and researchers in FN, especially 
people involved with tourism, the archipelago management, and the conservation of natural resources.

All data were compiled and set in a timeline to analysis according to TALC, following the application indicators of the method according to Butler (1980), Agarwal (1997), Tooman (1997) and Lundtorp and Wanhill (2001) presented in Falcão (2010). For each "Watching tourism" item in the timeline, where the main facts of these activities are presented, the indicators which led to the characterization and possible application of each stage of TALC for the activity "dolphin watching in $\mathrm{FN}$ " were bolded. Given the inexistence of historical data about the amount of tourist in each activity of dolphin watching in $\mathrm{FN}$, this information was not considered for the analysis.

\section{RESULTS AND DISCUSSION}

The Archipelago of $\mathrm{FN}$, which is $345 \mathrm{~km}$ far from Natal (State of Rio Grande do Norte), Northeast region of Brazil ( $3^{\circ} 50^{\prime} \mathrm{S}$ e $32^{\circ} 24^{\prime} \mathrm{W}$ ) is formed by a main inhabited island and 17 more islets, resulting in $26 \mathrm{~km}^{2}$ (Maida and Ferreira, 1997, Carleton and Olson, 1999). The estimated population of the region in 2016 is 5000 individuals. $\mathrm{FN}$ is currently a "territorial autarchy state district" that belongs to by the State of Pernambuco that therefore should manage the whole are and urban structure of the island. In the archipelago, there are two federal MPA: an Environmental Protection Area (APA-FN), established in 1986, and a Marine National Park (Parnamar-FN), created in 1988.

\section{The 1970's Historical development}

Tourist activities in FN started in 1969 when the Archipelago - then belonging to Brazilian Armed Forces (EMFA) and called Federal Territory of Fernando de Noronha (TFFN) - first received civilian visitors (Silva 2013). By this time, there was not an economic perspective of the tourism in the region (Cordeiro and Gomes 2016).

The FN airport was built between 1934 and 1942 during the Second World War by the US Army when the runway and the passengers' terminal were built. In 1975, there was an expansion for jet landing. Moreover, in the same year, daily flights to the island started. This is the exploration stage and the beginning of the involvement stage of the tourism in $\mathrm{FN}$, according to Falcão (2010). Tourism in FN was characterized by a small number of tourists with irregular patterns of visitation. By then, tourist activity did not have a significant economic importance to FN.

\section{Dolphin Watching}

Based on the TALC indicators, the exploration stage of the tourism in $\mathrm{FN}$ is also the exploration stage of the dolphin watching.

The dolphin watching started in the 1970's (Silva 2013). However, in the beginning, the activity was practiced informally with simple structures in fishing vessels (small, wooden boats) taking few tourists, relatives, and friends of the militaries working in the archipelago to a contemplative nautical trip with a stop at the "Carreiro de Pedra" Bay for bathing, swimming, and diving with dolphins. Along with the rise of the dolphin watching in $\mathrm{FN}$, this bay was renamed as "Dolphin's' Bay." Land-based watching, on the edge of this bay, started being practiced by this time. Later, this spot was known as "Mirante dos Golfinhos" (Dolphin Watching Deck) or 
"Mirante da Baía dos Golfinhos" (Dolphin Bay Watching Deck). For both land-based and boat-based, the activity happened without planning and structuring, characterizing the exploration stage of the TALC.

\section{The 1980's Historical Development}

In 1986, the Fernando de Noronha Environmental Protection Area (APA-FN Category $V$ of IUCN, APA-FN) was established (IBAMA 2005). In 1987, with the promulgation of the Law 7608 in 30 of June, the territory of the archipelago became civil instead of the military. Then, in 1988, the region left the Federal level to the State and was annexed to the State of Pernambuco. At that time, the tourism started as an activity that could bring income improvement for the population (Cordeiro and Gomes 2016). The first structures aiming tourism had few boats, minibus, and motorcycles. Little home hostels and inns received tourists (Silva 2013). This period may be considered as the involvement stage (Falcão 2010), because the government workers of the military period that decided to stay in the island started to create structures so they could receive more tourists to improve their income. Some residents' houses became home hostels and others started to offer a meal at home and to work as tourist guides. Common associations organized the local population and then the number of tourists increased.

In 1988, the Fernando de Noronha Marine National Park (Parnamar-FN Category III of IUCN, Parnamar-FN) (FUNATURA/IBAMA 1990) was established. Governors along with the private enterprise started to foresee a promising tourist activity in the archipelago, not including local population or the natural resources preservation. The creation of the ParnamarFN was motivated by the information released by Brazilian newspapers about the possible construction of large-sized works in the archipelago to the settle a 'large-scale, sophisticated tourism" and the preservation of the spinner dolphins population (FUNATURA/IBAMA 1990).

Zoning the APA-FN and delimiting the Parnamar-FN were based on the AgroEcological Zoning conducted by The Brazilian Agricultural Research Corporation Ministry of Agriculture, Livestock, and Food Supply (EMBRAPA) in FN in 1987 (Muehe 1989; Miranda 1994).

As the number of tourists rose in the island, in December 1989, a Tax Law (Lei Tributária do Distrito Estadual de Fernando de Noronha - $n^{0} 10403$ ) was sanctioned, giving the State of Pernambuco the tax jurisdiction of the District, which, among other taxes, set the Environmental Preservation Tax (TPA). This tax aimed to "assure the maintenance of the environmental and ecological conditions in FN, applying over the traffic and permanence of people in the area subject to the jurisdiction of the State District." In this way, any person aiming to arrive and stay in the archipelago must pay the tax previously of their arrival. Residents and workers (no matter in public, private sectors, third sector or researches) are not requested to paying the tax. This tax is still currently applied. In January 2017 , the daily charge was $U \$ 20.83$ until the tenth day of permanence.

\section{DolphinWatching}

With the annexation of the archipelago to the State of Pernambuco leading to the rising of the number of tourists in the island, the infrastructure for the dolphin watching 


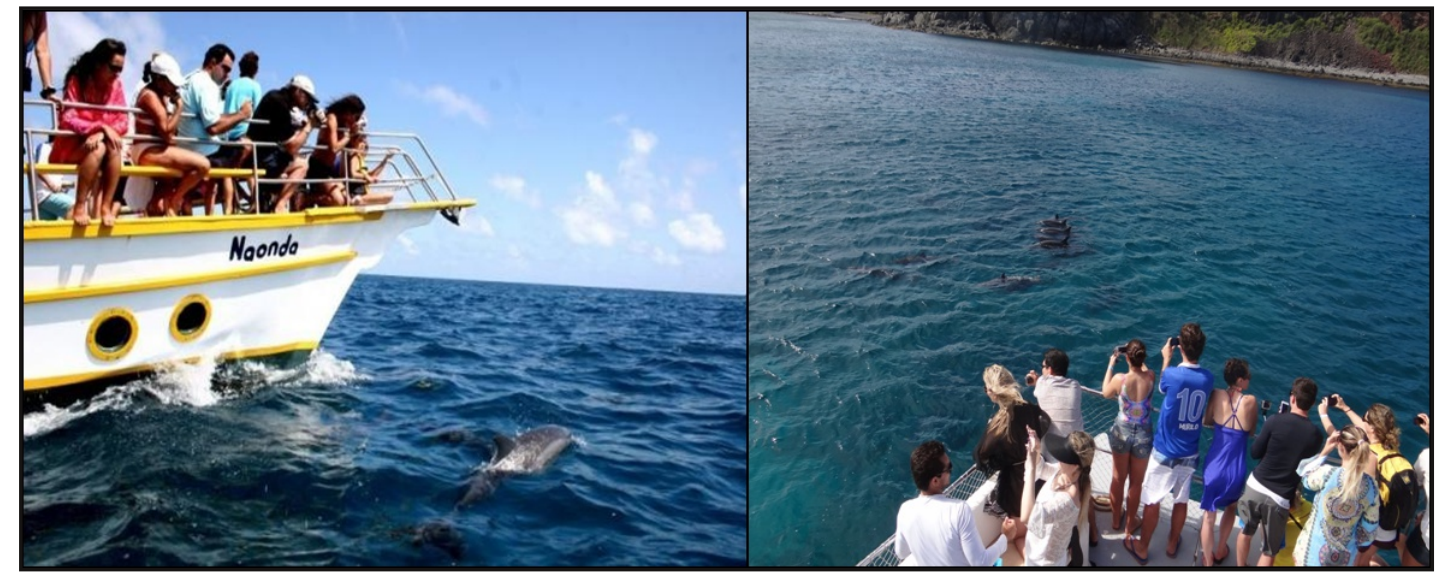

Figure 1. Observation tourism by boat in Fernando de Noronha. Photos: Spinner Dolphin Project Collection

trips started to change. Boats destined for the tourism were implemented, creating the "Boat trip" that is practiced until today, currently with the goal of watching the dolphins (Figure 1). Due to the increment of tourism, the Dolphin Bay was interdicted in March 1987 for diving and vessels. In 1988, with the creation of Parnamar-FN, more detailed rules were established along with an inspection program for those decrees. In 1988 , there was only one tourist boat in the archipelago (belonging to the Federal Government) and two private fishing vessels for tourists.

The route for the boat trip was then defined, and it is the same until today. It leaves Santo Antonio's Point (Figure 2 Point 1), goes to the secondary islands (Figure 2 - Point 2) all over Inside Sea until Ponta da Sapata (Figure 2 - Point 3), and stops at the front of the Dolphins' Bay (Figure 2 - Point 4). The route back is the same, with a 40-minute stop at the Sancho Beach (Figure 2 - Point 5) for bathing and diving.

By that time, the broadest federal law regarding cetaceans protection (Law 7643, from December 18, 1987) was promulgated, which forbids fishing and intentional disturbing of any species of cetacean in
Brazilian jurisdictional waters (Brasil 1987; Melo et al. 2013).

At the Dolphin Watching Deck, some residents who became tourist guides started to take tourists to watch the dolphins, which remain for hours in the bay.

\section{The 1990's \\ Historical Development}

In 1990, the Spinner Dolphin Project was established, acting on the research and conservation of spinner dolphins of $\mathrm{FN}$. Researchers of the Project began to do daily watching for biology, ecology and behavior research about the spinner dolphins at the Dolphin Watching Deck, freediving at the Dolphins' Bay and near areas, and onboard around the archipelago. The researches remain until today.

From 1996 to nowadays, there are thirteen dolphin watching boats in ParnamarFN and most of them were changed and have now different owners. After this year, the Brazilian Institute for Environment and Natural Renewable Resources (IBAMA), at that point managing the MPA, ended conceding authorizations aiming that the number of boats did not rise in the archipelago. Boats that arrived in FN after 


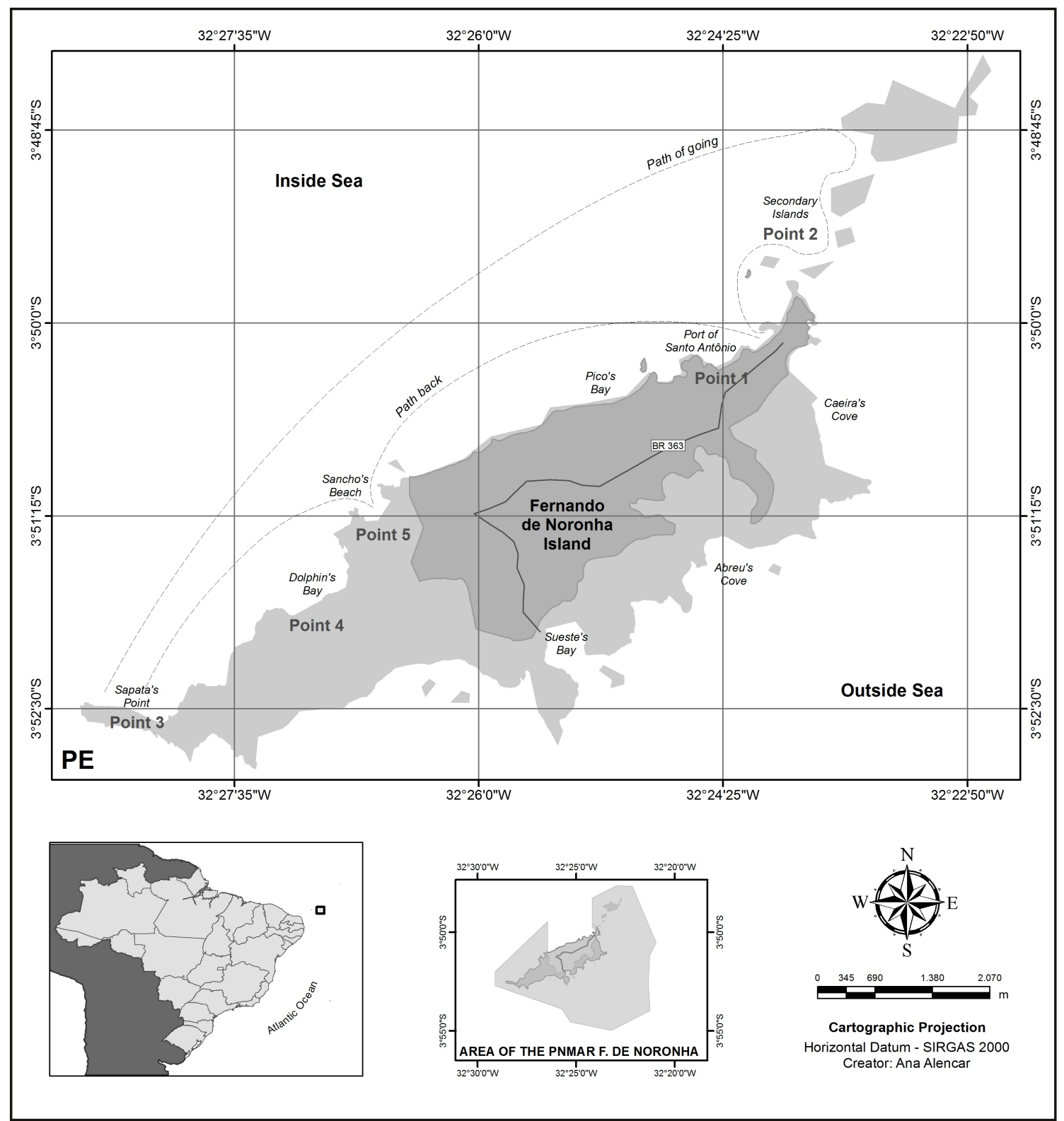

Figure 2. Location of the Fernando de Noronha Archipelago, with limits of Parnamar-FN and APA-FN and itinerary made by the boat trip for dolphin watching. Port of Santo Antônio - Point 1, Secondary Islands - Point 2, Sapata's Point - Point 3, Dolphin's Bay - Point 4 and Sancho's Beach - Point 5.

this period have authorization only for traffic in the APA-FN. Nowadays, ten out of the thirteen ships with permission perform regular boat trips (they conducted more than 100 visits in 2015); the other boats make occasional trips or are in maintenance.

On this period, there was an improvement of the tourist infrastructure and the concern about environmental preservation and conservation of the archipelago. In 1996, the Tamar Project (dedicated to the research and conservation of sea turtles species occurring along the Brazilian coast) already had a research center in FN and opened the Visitors Center and the Open Museum of the Sea Turtle. Beyond having informational panels, sea fauna sculptures, and souvenirs shops, the Visitors Center have an 
auditorium where free lectures related to environmental themes for residents and tourists are given daily with an average of 1500 visits/month (Vale et al. 2016). One of the talks presented since the start of the project describes the spinner dolphins and the Spinner Dolphins Project.

The number of hostels, restaurants, tour and receptive tourist companies and souvenir stores have increased during this period, characterizing it as a developing stage of tourism in TALC (Falcão 2010).

\section{Dolphin Watching}

The dolphin watching is the developing stage for both onboard trips and the Dolphin Watching Deck. As visits are now well defined with a schedule and itinerary, the advertisement to attract tourists has been intensified.

Watching from the 'Dolphin Watching Deck' has become an option to tourists that watch the dolphins and receive information from the Spinner Dolphin Project researchers. Access was done any time through a near 1000 meters track laterally delimited with rocks. The state of conservation of the track was precarious
(Figure 3), in a way that the access is hard to people with disabilities, especially in the rainy season when the mud accumulation is intense.

Resting, reproducing and parental care behavior of the spinner dolphin can be observed from the Dolphin Watching Deck. Activities at the surface and leaps are characteristics of this specie and are commonly observed (Figure 4).

A concern on the possible impacts of the increase of watching tourism over cetaceans emerged. In this way, laws and norms began to arise with national and local range. In 1995, "Ordinance 05 of IBAMA, Brazilian institution managing the MPA, established that it is forbidden to touch, feed, and persecute dolphins anywhere in the archipelago. During boat trips, any sound disorder is forbidden. The document also manages the displacement of the ships, and it is specific for protecting the spinner dolphins in FN (IBAMA 1995). On December 26, 1996, the "Ordinance 117 of IBAMA, with national range, defined the disturbance levels, setting general and specific rules for some baleen whale species (IBAMA 1996). A more specific legal provision about one of the practices of cetacean tourism was

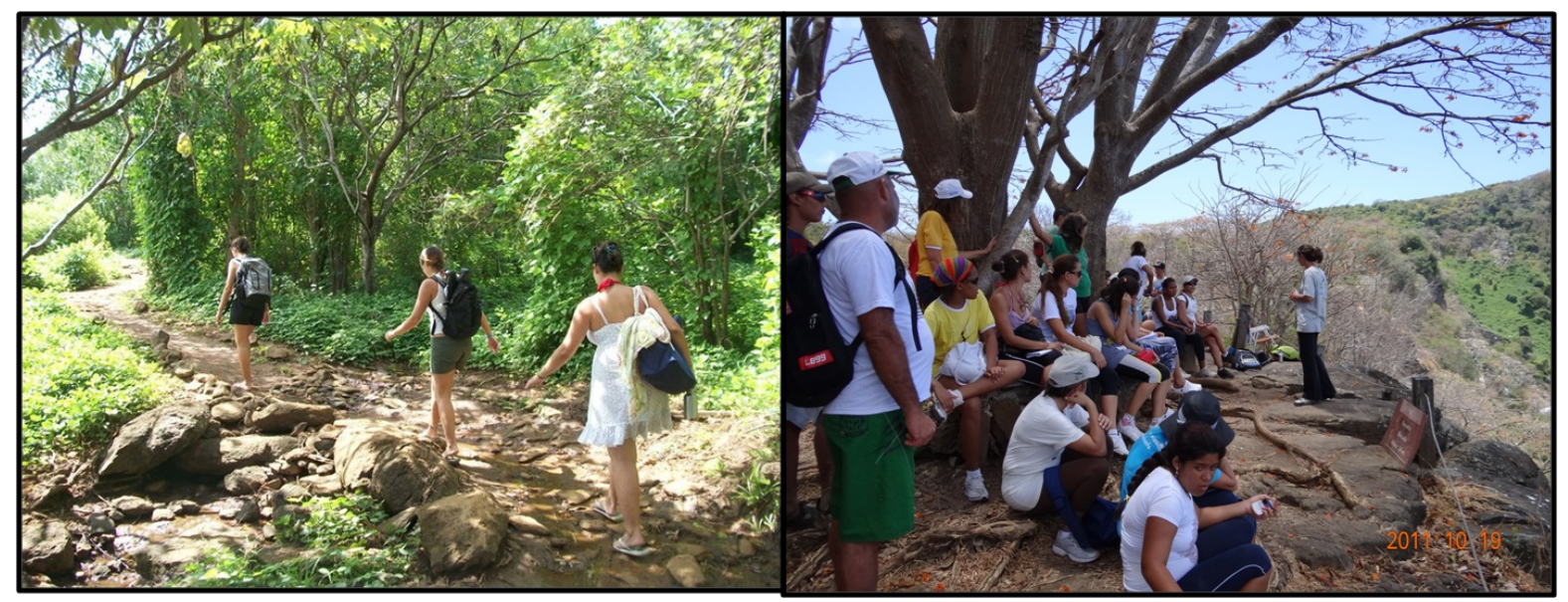

Figure 3. Access trail and Dolphin's Bay Observatory until the 2000's. Photos: Spinner Dolphin Project Collection. 


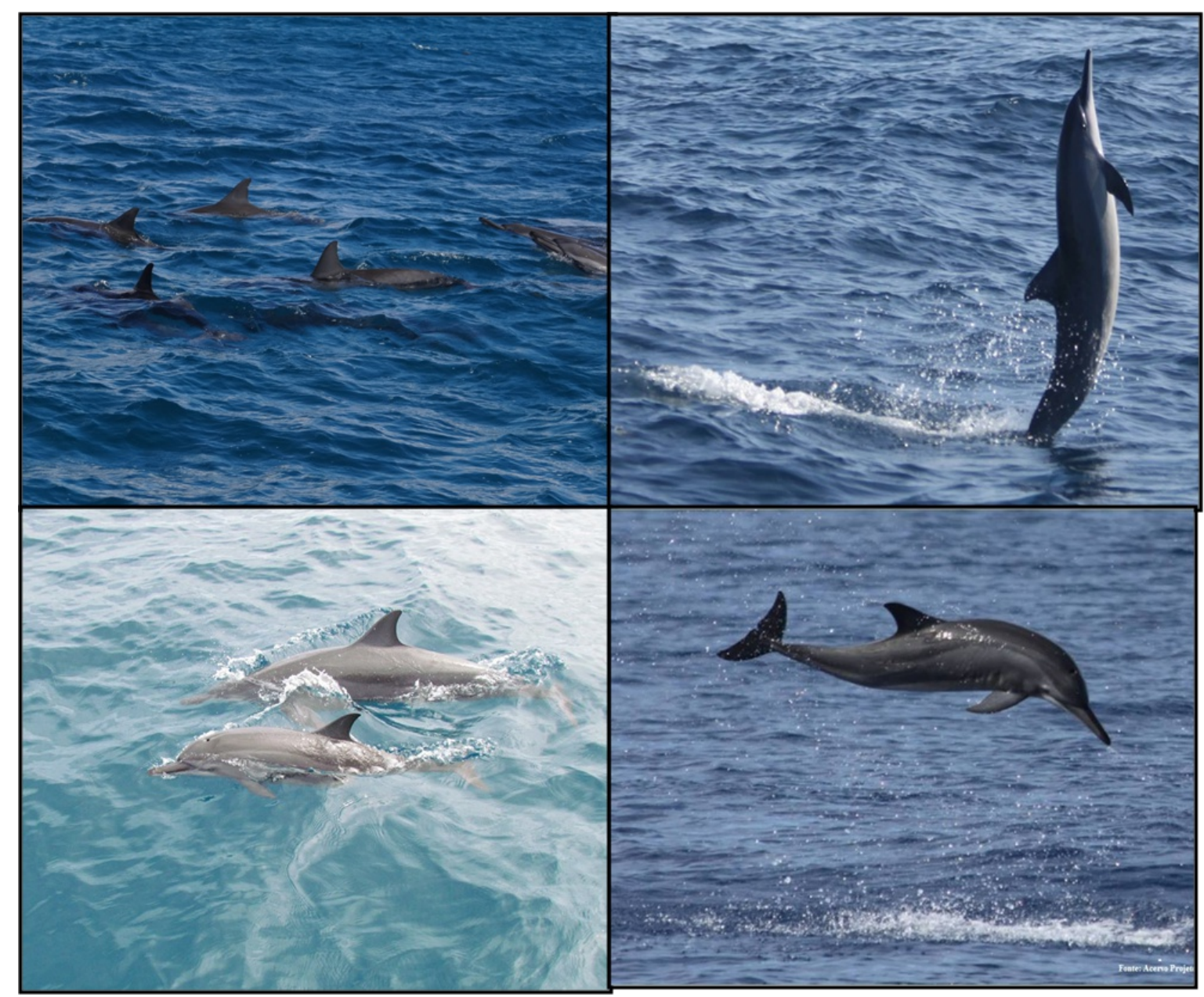

Figure 4. Behaviors of spinner dolphins observed from the Dolphin's Bay Observatory in Fernando de Noronha. Photos: Spinner Dolphin Project Collection.

established in 1999 by the Normative Instruction of State District of Fernando de Noronha 04, which forbids intentional diving with any dolphin species in the APA-FN area (ADM-FN 1999).

\section{The 2000's Historical Development}

In 2001, the archipelago was nominated as a Natural World Heritage Site by UNESCO, mostly because of the Dolphins' Bay, the importance of the archipelago for many sea species, and the scenic beauty of the beaches (UNESCO 2001).
Advertising about $\mathrm{FN}$ and its natural beauties becomes intense. Images of dolphins are present in an advertisement of the archipelago in many visual communication media, in visits, in the pattern to classify lodgings, in the logo of the District Administration (ADM-FN) and for many other purposes of referring to $\mathrm{FN}$ (Figure 5).

Nineteen years after its creation, the APAFN has its managing plan published (IBAMA, 2005). Among other regulations, the Plan defines the procedures that must be accomplished by any watercraft, its crew and responsible companies in the area of the 


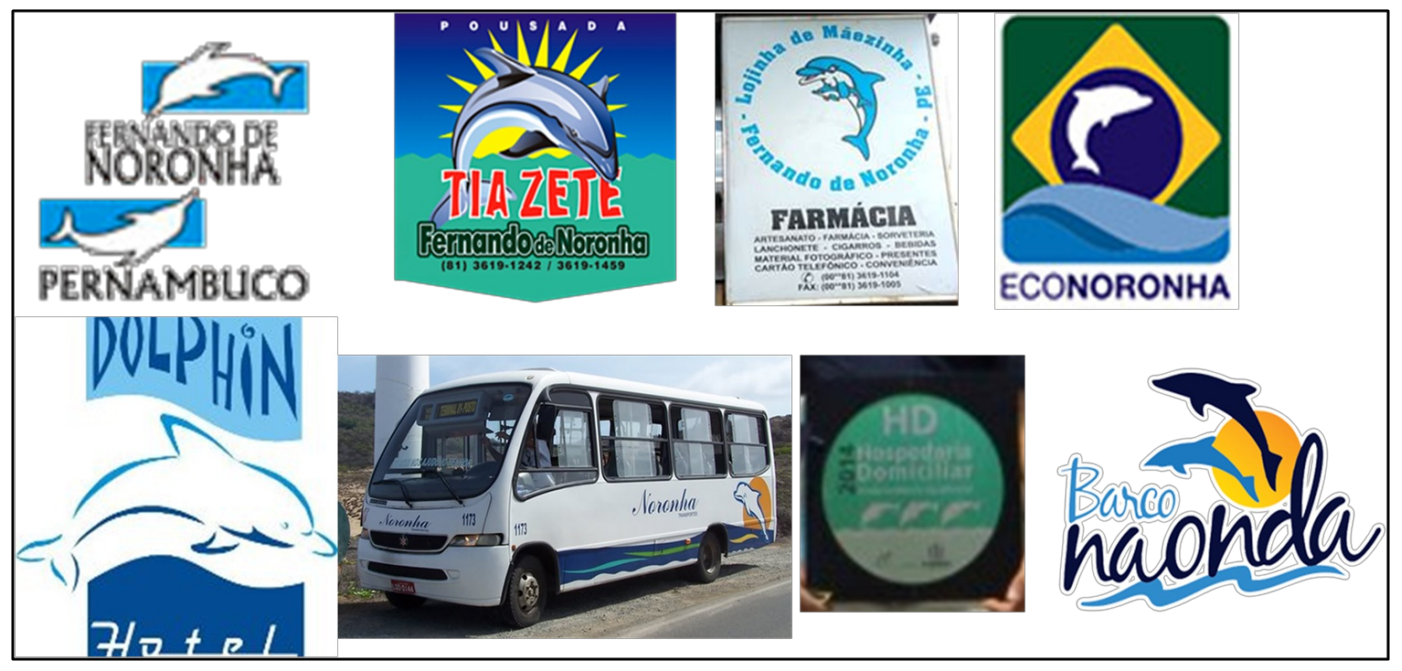

Figure 5. Dolphin images used in different ways as a reference to Fernando de Noronha.

APA-FN and it especially highlights about the need of regulating the register and authorization for vessels by IBAMA and ADM-FN. The records by the Ports Authorities and adjustments according to Brazilian Navy rules are also highlighted.

Some years later, the Supporting Capacity Study and Determination in APAFN was published and its Sustainability Indicators, proposed, among others, the following restrictions for vessels

- up to 8 fishing vessels operating in Noronha, not longer than 10 meters and with engines with most two cylinders;

- up to 35 vessels circulating;

- having in account that these boats have an average capacity for 18 passengers (varying from 3 to 50 ), and, at the same time, following the recommendations for a maximum circulation of 35 vessels;

- a projection of at most 600 tourists a day in trip boats in FN.

Aiming to control tourist activities in Parnamar-FN, the institution that manages the MPA, now called " - (ICMBIO) - Chico Mendes Institute for Biodiversity Conservation" publishes the Carrying and Operationalization Capacity Study on the
Nautical Tourism Activities in Parnamar-FN" (Luis-Jr 2009). This study deals with many nautical activities and, among its goals related to boat trips, it purposes an adequate managing of this activity beyond preserving the ecological condition of the spinner dolphins to make it economically possible, suggesting as practical actions that:

- up to four boats must sail at the same time in front of the area the dolphin's use (Dolphins' Bay and Entre Ilhas) and a minimum 400 meters distance from the signaling buoys;

- small boats (less than 20 passengers) with outboard engines and motorboats with outboard or center/tail engines are forbidden from navigating inside the park.

This is the consolidation stage of the tourist activity in FN, according to Butler's model (1980). The amount of visitors surpasses the number of residents and almost the whole economy of the island is connected to tourism (see Falcão 2010 for more information).

\section{Dolphin Watching}

This is the decade of the consolidation for 
the two kinds of dolphin watching visits in $\mathrm{FN}$. The indicators of this stage of TALC are recognized for dolphin watching trips in $\mathrm{FN}$.

With the high advertisement of $\mathrm{FN}$, both nationally and internationally, and the dolphin as a major symbol, the amount of tourist looking for dolphin watching trips keeps increasing.

At the start of the watching tourism activities in $\mathrm{FN}$, the crew used to give general information about the island and the dolphins because there were not professional courses to capacitate these workers. In 2000, the Spinner Dolphin Project started a professional capacitating program in ecotourism for the residents of the island (Pereira et al. 2015), providing a more professional aspect to the visits.

By this time, a local tour company commercialized the product "Dolphin Watching Deck Tour", with a daily group of tourists going to the watching deck at 6 am to watch the dolphins arriving at the bay, including the round trip transfer from the lodging (the most challenging component to access the Watching Deck). This formally dealt trip lasted only a few years because of the drop in the number of tourists and was canceled by the company. Then, the way through the Dolphin Watching Deck is incorporated into a trip through the track, including a beach and another watching deck to contemplate the landscape, with no schedule. The boat trip does not face this dropping indicator about the number of tourists.

Due to FN district laws, the ownership of companies settled in FN (related or not to the tourism) must necessarily belong to a "resident," who is defined and registered by the ADM-FN. This avoids significant national companies from being in charge of the local economy. So, to either Dolphin Watching Deck with local tourist guides and businesses or the boat trip (with residents as boat owners and the crew), the dolphin watching became essential to the local economy during this period.

On December 17, 2008, the Brazilian Government by the presidential decree 6698, declares the Brazilian Jurisdictional Waters as a Sanctuary of whales and dolphins, aiming to preserve them and to promote non-lethal uses of animals, such as the whale watching in an organized manner (Brasil 2008).

\section{0 to nowadays Historical Development}

In a review of the Nomination Documentation from 2001, Unesco (2015) shows concerns on the rising amount of visitors and the presence of invading exotic species in the archipelago (Tolledo et al. 2014; Mello 2014). The correct management of the tourism is recommended, and the increment of the number of visitors is shown by the presence of 90.522 tourists in the FN airport in 2015. These numbers show an increase of $18.8 \%$ compared to the previous year (ADM-FN, 2015).

In 2013, aiming to improve tourist structures in the Parnamar-FN, the MPA managers called a public tender to the concession of these services to a private company through a Real Rights Concession Contract (CCDRU). Some structures to control the number of tourists were built to improve customer service and accesses, allowing people with a mobility impairment to visit the region and an entrance fee was created. In January 2017, the entrance fee was US\$31.3 for Brazilian tourists and US\$62.9 for foreigners, permitting for a consecutive period of 10 days for visiting. The access is free to the APA-FN, without control of the number of visitors and no 
entrance fee, as set by the National System of Conservation Units (SNUC - Law $n^{\circ}$ $9985 / 2000$ ), ruled by the Decree 4340/2002.

According to Falcão (2010), until 2009 (the final investigated period), FN presented indicators of both developing and consolidation stages. However, in the early years of the 2010's, the tourism in FN presented indicators of the TALC's stagnation stage. The number of tourists was increasing year after year, surpassing the island infrastructure capacity, especially for the water and sewage treatment and solid waste disposal and treatment. Moreover, the environmental, social, and economic issues became common. As there was no renewal of the tourism management or a thought change, the high cost of traveling to $\mathrm{FN}$ did not match the infrastructure found by tourists when they entered the archipelago. With the concession of Parnamar-FN to a private company and the revitalization of this area, a rejuvenation stage appeared to start with the improvement of some structures.

Until December 2016, the tourism-related infrastructure in FN included 118 lodging spots, 41 restaurants, bars and snack bars, seven receptive staff and tour companies, five independent diving companies, and 13 car rental agencies (ADM-2016).

\section{Dolphin Watching}

This decade shows the stagnation and rejuvenation indicators for both kind of dolphin watching visits in FN.

The concern on the impacts of tourism was intensified. In this way, in 2011, the ICMBio (Ministry of the Environment) published the "National Action Plan for Small Cetaceans" (ordinance 86, from 27 August 2010) with the goal of reducing the anthropic impact and enlarging the knowledge about small cetaceans in Brazil. In this document, action researches about the interaction between tourism and spinner dolphins in $\mathrm{FN}$ are set as priorities (ICMBio 2011). Some researches were conducted and showed that the negative impacts of onboard tourism are evident in FN (Tischer et al. 2013; Tischer et al. 2017).

From 2013 on, with the concession of Parnamar-FN, the access to the Dolphin Watching Deck was improved. The tour begins at the Golfinho Sancho Checkpoint (PIC Golfinho-Sancho), disposing of a parking lot, toilets, showers, snack bars, souvenir shops, and lockers. The visiting period varies from 6:30 am to $6 \mathrm{pm}$. From the PIC Golfinho-Sancho, there is a suspended 942 meters track to get to the Watching Deck (Figure 6). This route is selfguided, being unnecessary the company of a registered guide. If the tourist decides to get a guide, he must adequately register at the MPA managing institution.

Beyond informative signs about dolphin behavior, a research team of the Spinner Dolphin Project provides information and binoculars to the tourists. Moreover, this group of researchers monitors the occupation of the dolphin by the creek from Monday to Saturday from 5:30 am to $4 \mathrm{pm}$.

By the end of concessions authorizing boat traffic in the Parnamar-FN in 1996, new nautical activities appear as the carrying capacity of the Parnamar-FN was reached. Beyond the traditional boat trip, other onboard activities are practiced in the archipelago, such as free diving, plana-sub (freediving with a board pulled by a cable) and sunset visits (Table 1). During this period, stand-up paddle boards, kayaks, and Hawaiian canoes for rental are first seen. The increment of the number of vessels and other nautical vehicles was remarkable, once that in addition to the 
thirteen dolphin watching trip boats, nine autonomous diving vessels are operating in the Parnamar-FN, in addition to twenty-three other tourism boats, a free diving one, and thirty fishing vessels that operate in FN.

Nowadays, even with a formal and structured tourist activity in the archipelago, little information is given to the tourists by the moment they buy the boat trip. During the trip, a registered guide or member of the crew provide the tourists with information about the beaches, curiosities, and history. When the tourist meets the dolphins, they get necessary information about the animals'

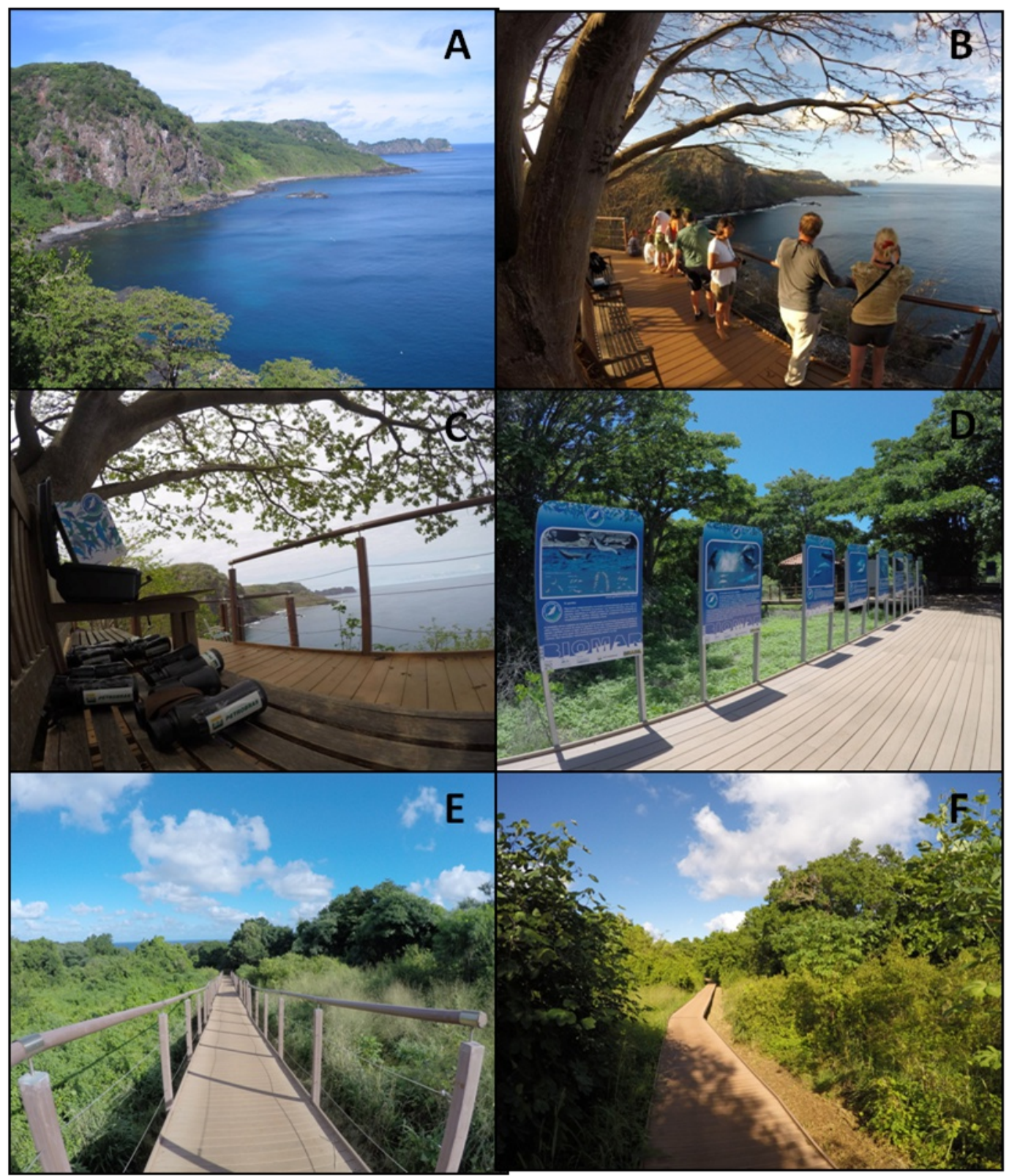

Figure 6. Dolphin watching of spinner dolphins from land in Fernando de Noronha. Present days. A Dolphin's Bay, B - Dolphin's Bay Observatory, C - Information material and binoculars available free of charge at the Dolphin's Bay Observatory, D - information signs, E and F- access trail to Dolphin's Bay Observatory. Photos: Spinner Dolphin Project Collection. 
behavior and laws. In January 2017, the cost of the trip varied among companies, from US $\$ 29$ to US $\$ 58$. There are many kinds of vessels used for this trip, including small wooden boats with inboard engines, large schooners, and outboard engine boats.

Besides scuba diving, the other visits are practiced in the APA-FN area and mostly by outboard engine motorboats. In addition to being more concentrated and more permanent in the Parnamar-FN area, a group of dolphins can be found moving all the archipelago around, especially in the morning (Tischer et al. 2017). In this way, all the other onboard activities can show the animals in a way to intensifying the negative impacts on the dolphins.

\section{Demand for the cetacean watching tourism in FN}

From 1995 to 2015, the annual average of tourists coming to $\mathrm{FN}$ by air transport was of 51809 people (AMD-FN 2016), with an increasing trend. Based on the monthly average of the number of tourists over these years, it is noted that spring and summer are the high tourist seasons, going along with the scholar holidays in Brazil (January and July), the vacation in Europe and other emitting countries. Brazilian national holidays like September 7 (Independence Day), November 15 (Republic Proclamation) are also traveling dates from Brazilian people, especially during long weekends. The other months present values under the average with low tourist activity.

The off-season matches the rainy season, from March to June. The tourist profile also changes throughout the year, either because of environmental, social or economic variables of the place of origin.

Once the boat trip is a more traditional trip to the island and is included in most of the tour packages, this visit has a more significant demand than the Dolphin Watching Deck (Figure 7). The closest proximity with dolphins is also a feature that favors the boat trip.

The tourists' average length of stay on the island in 2015 was 5.5 days (AMD-FN 2015). Usually, the first two or three days of stay are reserved for pre-scheduled trips by the travel agencies, making the Dolphin Watching Deck as an extra trip for tourist staying longer and with particular interest on

Table 1. Type, number and characteristics of the vessels currently used for nautical and tourist activities in Fernando de Noronha.

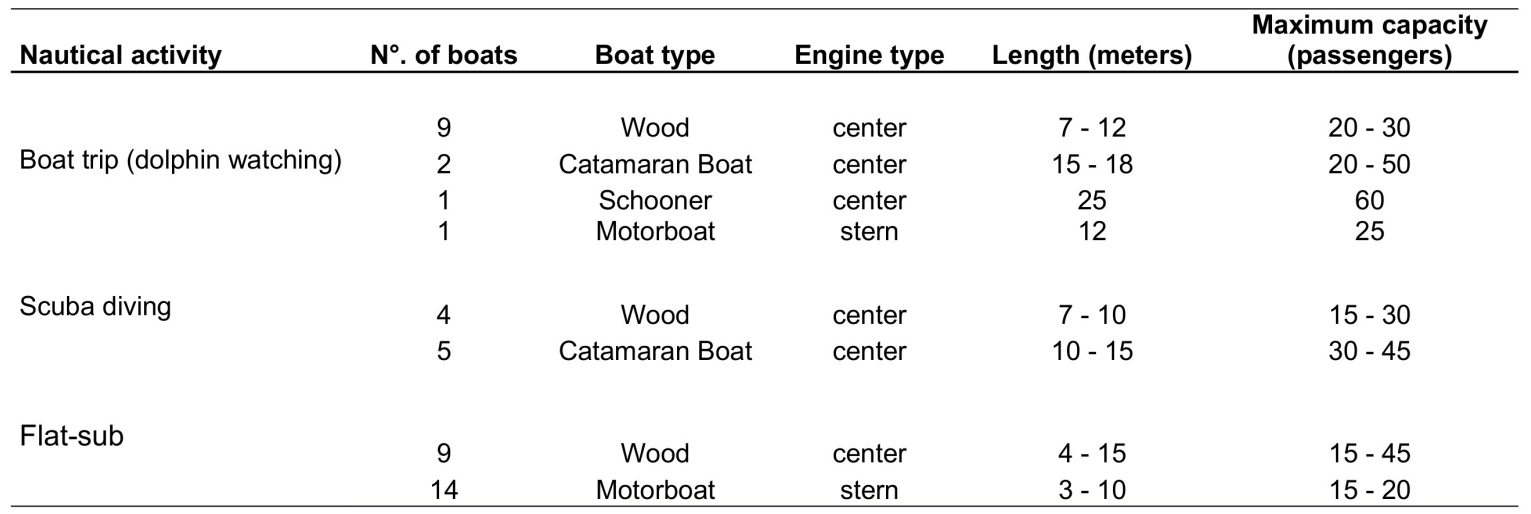

NOTE: Some vessels are used for more than one type of activity; however, these are accounted for only once, in its main activity. 


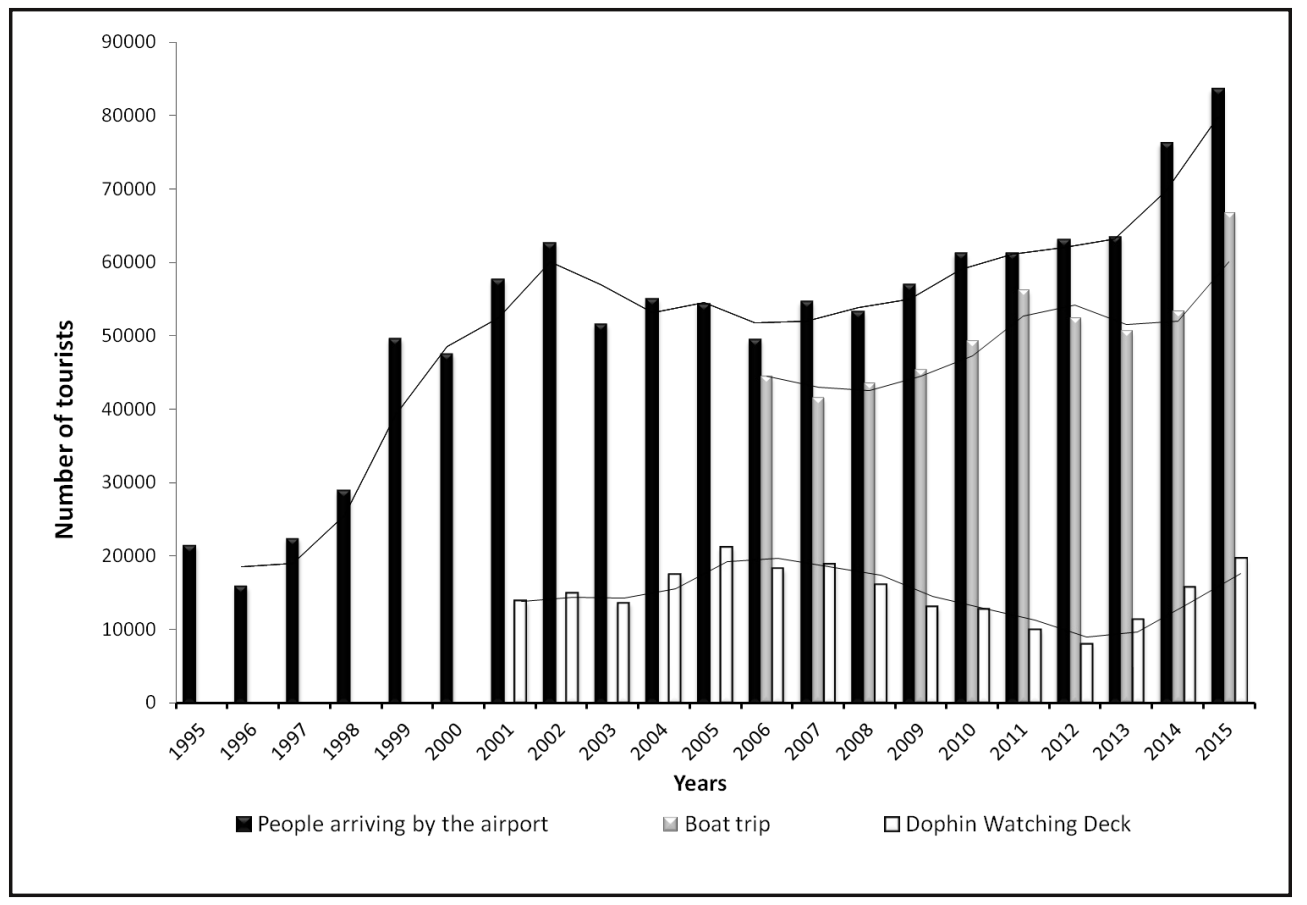

Figure 7. Total number of tourists in Fernando de Noronha and in every activity of tourism, boat trip and Dolphin's Bay Observatory, in the years 1995 to 2015. (Data source - Coordination of Ecotourism - Administration of the State District Administration of Fernando de Noronha, Spinner Dolphin Project and Marine National Park of Fernando de Noronha - ICMBio).

watching the dolphins.

According to information from the Administration of the State District of Fernando de Noronha, Ecotourism Department, Parnamar - FN (2015) and The Spinner Dolphin Project (2015), 81\% of the tourists chose the boat trip and $23 \%$ look for the watching by the Deck. The data also show a highly significant correlation between people arriving in Noronha and having the boat trip (Pearson Correlation $=0.725, p<$ $0.001, \mathrm{~N}=108$ months). As for the Dolphin Watching Deck trip, the correlation is low but still positive (Pearson $=0.337, p<0.001$, $\mathrm{N}=108$ months). Therefore, the dolphin watching tourism in $\mathrm{FN}$ is required by the tourists no matter the season and with high frequency.

\section{DISCUSSION}

The sustainable development of the tourism implies the conscious management of the natural resources it relies on, for these resources and the associated travel can be held over time (Stewart 1993). Benefits and losses are expected (Stewart 1993), and in $\mathrm{FN}$, the benefits resulting from the conservation of the natural resources have been one way to conserve the spinner dolphins.

Along with the tourism development in FN, two options of activities for the spinner dolphin watching were established. The traditional boat trip or any other way of interacting with nautical vehicles is potentially the cause of adverse impacts on animals, which requires more attention in researches and managing and law decisions. 
Tischer et al. (2013) show that some watercrafts in FN do not follow the laws, mainly because of the move in high speeds next to the dolphins, causing a more significant reaction from the animals. Studies with other populations of spinner dolphins have shown worries about the effects that repeating human-dolphin interaction might have on dolphins (Courbis and Timmel 2009; Delfour 2007). The cumulative exposure of spinner dolphins to human activities can change its energetic load and, in the longterm, the population viability as studied in Bejder et al. 2006 and Lusseau et al. 2006 for other species. One of the immediate afterward consequences of the intense traffic of boats is the danger of crashing. Direct impacts of running over have been already registered in $\mathrm{FN}$ by Camargo and Bellini (2007) who recorded a spinner dolphin in FN with wounds indicating that a boat ran over the animal.

Boats currently used for the dolphin watching in $\mathrm{FN}$ are most with inboard engines. However, for other nautical activities, outboard engine boats are more used. According to Au and Green (2000), inboard engine boats are mostly recommended for watching tourism activities for being less noisy in the water. Each dolphin watching boat in $\mathrm{FN}$ makes one trip each period (morning and afternoon) due to its most prominent passengers' capacity and the length of the journey. As for the other nautical tourist activities, small boats with fewer passengers are used in shorter visits, so the same boat makes more than one trip by a period. In this way, these activities increase the chances of interaction with dolphins, as well as the elevation of noises in the environment. The rising number of small vessels with outboard engine (e.g., canoes) or without an engine (e.g., stand-up paddle boards) are standard in the APA-FN.
Such boats promote an issue to the environment institutions in the archipelago.

The lack of other proper habitats for a species may promote that the populations remain in places where they are suffering impacts (Gill et al. 2001), just like cetaceans target of watching. For this reason, the long existence of places where there is whale watching does not mean the absence of impact on the whales and dolphin populations, as in FN. Management strategies that minimize the effects of whale watching activities are being developed (Chion et al. 2013). Tyne et al. 2015 suggest the creation of population free priorities areas of conservation for the spinner dolphins in Hawaii, where they are also an intense target of the dolphin watching.

Anthropogenic interactions can be as harmful to the animals as natural interactions (Frid and Dill 2002). The resulting risks of these interactions can lead to a trade-off between the necessary investments to avoid the risk and the investment in other activities, such as feeding and reproducing (Frid and Dill 2002). Even regulated events happening inside the MPA, as in ParnamarFN and the APA-FN might have potential impacts. Thurstan et al. (2012) analyzed the effect of 16 activities inside the MPA and how they negatively affect the goals of conservation of these areas. The authors emphasize the high potential impact of engine boat trips, including those used for whale and dolphin watching on the sea life and in the environment if there is no proper management.

Many aspects of the whale watching were widely discussed in a series of workshops produced by the International Fund for Animal Welfare (IFAW). In 1997 (IFAW, 2000), the workshop discussed the ethics codes and legal aspects of the activity aiming to formulate recommendations that 
protect the species. In the report of these events, there were no references to Brazil. However, the report is a critical document for comparing the current Brazilian legal aspects about the whale watching with the international laws. We can observe that international agreements, such as the creation of Sanctuaries, are essential. Regulations about the whale watching are countries and states' responsibilities, with wide variation. A common point in the workshop was the urge of adopting the "precautionary principle" to create law, norms, and ethics codes (IFAW 2000).

Some laws from the document have been updated, such for Australia, with the creation of the Australian National Guidelines for Whale and Dolphin Watching in 2005, a national politic replacing the version published in 2000 (Australian Government 2015). The Australian and the Brazilian legislation have similar approaches. However, the speed of vessels descriptions of the Australian law is more detailed and covers more points in the national aspect. In Brazil, only the " - Ordinance 117" from IBAMA deals with norms about the proximity of boats to groups of cetacean, mostly for baleen whales. In Argentina, Valdes Peninsula is famous for the whale watching , with the southern right whale (Eubalaena australis) as the principal target. Nowadays, the Provincial Law 5714 from 2008 is the legal provision in existence. Besides the norms that control the proximity of vessels, this law forecasts public tenders for companies wishing to execute this activity, with a tax paid to the Province (Sironi et al. 2010). However, Chalcobsky et al. (2017) still indicate failures in the legislation, and due to changes in the biological system of the species, some aspects can be improved to make the rules more easily modified. In Brazil, no travel agency doing the whale/dolphin watching pay taxes addressed to programs to research and conserve these animals.

In $\mathrm{FN}$, documents such as the Management Plans of both MPA (FUNATURA/IBAMA 1990, IBAMA 2005), the Carrying Capacity Studies (Luís-Jr 2009; Elabore 2008) along with laws and normative instructions for the whale watching are not enough to minimize the impacts of dolphin watching on the spinner dolphin population of the archipelago. The lack of equipment and supervisory organ (ICMBio) personnel and the lack of medium and long-term environment conscious by the community make the norms inefficient. The limits for the number of trip boats as quoted in the Carrying Capacity Study in the Parnamar-FN (Luís-Jr 2009) are not observed by the tour operators and are not controlled by the ICMBio either. The population does not support mitigating actions such as boat propellers protectors and the protections of new areas free from tourist activities to guarantee the stay of dolphins without impact.

According to the data from the Ecotourism Department at the ADM-FN, the number of tourists in $\mathrm{FN}$ is increasing year after year. This fact warns about its consequences that must be carefully watched. Impacts may occur on environmental, biodiversity, social, and economic aspects at the expense of the tourism growth.

According to the TALC stages (Butler 1980) for a tourist destination, $F N$ is currently in the stagnation stage, in which the capacity levels have been exceeded for many sectors. The number of vessels in the archipelago and the number of visits they make are out of control, especially in the APA-FN, despite the existence of a "Nautical Carrying Capacity Study for the Parnamar- 
FN" (Luís-Jr 2009) and a "Carrying Capacity Study for the APA-FN (Elabore 2008). The sewage, water treatment, and waste collection systems, which should be managed by the State of Pernambuco's government, are undersized for the residents and tourists in the island each year, causing social, economic and environmental issues. In 2013, with the concession, some areas and services of public use in the ParnamarFN had a revitalization process.

The future of the FN tourist destination is still uncertain. Few actions trying to follow the TALC's rejuvenation path can be noted. However, the lack of medium and long-term planning and the environmental consciousness by the population, the recurrent conflicts of ideas between the ecological institutions and the community, and the individual thought overwhelming the collective one suggest the stagnation path in FN. A decline is unlikely, as the natural beauties of the archipelago still overcome the obstacles of the high cost of the destination for both national and international tourists.

The Butler approach (1980) was applied for some other insular destinations, such as Tenerife (Rodríguez et al. 2008), Isle of Man (Cooper and Jackson 1989), Paradise Islands - Bahamas (Debbage 1990) among others. Zhong et al. (2008) applied the model to a National Park in China created in 1982 and observed that the area is at the consolidation stage. The cycle in FN, throughout five decades since the first tourist activities started and four decades of MPA, led the region to the last stage. In 2013, Feitosa and Gómez (2013) verified the environmental impact of tourism in the archipelago using the Tourism Ecological Footprint Method. They concluded that the tourism in FN had an adverse effect on the natural ecosystem due mostly to the displacement of tourists to the archipelago, done by air transport, and the electric energy producing system by burning fossil fuels in the "Usina do Tubarão" thermoelectric power plant.

The recognition of the TALC indicators for the dolphin watching in $\mathrm{FN}$ was possible for both activities: land-based and boat-based. Each TALC stage happens concomitantly for both the destination and the active development, with the last depending on the destinations, on the number of tourists, the increase of environmental impacts, and impacts on the local economy. For tourist destinations, the application of the TALC to a tourist activity presents limitations (Agarwal 1997), especially at the definition of the transition point between the stages.

The constant presence of governmental and non-governmental environmental institutions and the researches in $\mathrm{FN}$ led to some preventive actions against the ecological impacts of the onboard dolphin watching. The Dolphin Bay was closed for boats and divers and the concession of boat traffic authorizations in the Parnamar-FN was ended. Even though, these activities did not avoid the increasing number of vessels in the APA-FN area. Some external events can contribute uniquely to how the boat trip developed. The rise of the presence of dolphins in APA-FN regions may induce the outbreak of new nautical activities, besides the traditional boat trip. The presence of external factors influencing the development of the destination was discussed by Agarwal (1997).

The premise of the TALC model is that, in case of limitless tourist development and growth, the region will likely be unsustainable (Butler 1980, 2004), such as observed for the dolphin watching in FN. An increase of the negative impacts and the stress of the animals provoked by the boats 
may reduce their appearance in the archipelago, predicting the decline poststagnation stage of the activity for on-water watching and consequently for the landbased watching.

The educational component of the landbased dolphin watching in FN is more evident given that most of the time a qualified research team is at the Dolphin Watching Deck to do the research and provide information to the tourists in addition to the existence of informative panels and press material. However, this may not be observed for the boat trip, in which a brief information is given to the participants. In addition to the mandatory capacitation courses to the service providers so that they can work inside the Parnamar-FN area, the acquired knowledge is not applied. Krieger and Chadwick (2012) demonstrated that, by measuring the effectiveness of educational practices before recreational diving and the harms caused to coral reefs in Florida, the divers are getting more full briefings with environmental information, leading to less damage to the reefs when compared to divers getting no information about the conservation. Therefore, especially for the boat trip, the educational component must be intensified, so the knowledge and the consciousness about the possible impacts are then part of the experience, together with the legislation and the creation of an ecological awareness in the participants.

The demand for both activities, however, is not the same. Our data showed a strong correlation between the number of tourists and the demand of the boat trip and a weak correlation between the number of tourists and the demand for the Dolphin Watching Deck tour. Such observations may result from the short stay of most of the tourists in FN. The fact that boat trips are prescheduled in the tour packages and the significant chance and proximity to dolphins make many tourists with no particular interest on the animals to not seek for the Watching Deck trip. The access to the visits is also a factor that must be considered, once agencies offer the round trip transfer. For the Deck trip that does not require a guide, the tourist needs to rent a car, hire a taxi service or take a bus. The last itinerary does not reach the PIC Golfinho-Sancho, so part of the path must be done by walking. Moreover, the tourist must travel in the early morning hours due to the dolphins' behavior. This more prominent logistics also makes that tourists look less for the Deck trip than they do for the boat trip.

Stewart (1993) favors the sea conservation as a strategy to control tourism in coastal and sea zones. In this study, the author warns about the increasing popularity of onboard activities that, besides of raising the discharge of pollutants, such as oil, can increase the disposal of solid wastes. This increasing trend for the boat trip is a reality in $\mathrm{FN}$, not only for the dolphin watching but also for many other leisure options. Careful monitoring and management must happen and the shutdown, if necessary.

\section{CONCLUSION}

This novel proposal of applying the TALC for a tourist activity was possible, recognizing the indicators of each stage with the same limitations for referring to a destination. The overlap between stages was verified, mainly because the development of the activity occurred together with the development of the destination.

The perspective of a sustainable watching tourist activity is only possible with four factors together: planning, research, monitoring and management for 
conservation. The economic benefits that the dolphins bring to $\mathrm{FN}$ have already been proven (Dunker 2005). However, the significant challenge is still to conciliate the operation of the activities, economic gains, and conservation. We observed that tourism and the dolphin watching in $\mathrm{FN}$ are practiced without prior planning. Opportunities are identified by people and the tour operators promote new trips or expand their activities without consulting the governmental and environmental institutions. The issues resulting from this lack of planning made FN to be managed (on its social, economic and ecological aspects) to solute problems that should be avoided with prior action planning. The lack of structure of the monitoring institutions (governmental, environmental or state) and people's consciousness and knowledge make the current legislation, even having blanks, not to be applied and monitored. This leads to an inefficient protection of the environment and biodiversity of FN (terrestrial or marine) and an ineffective action for sustainable tourism, which compatible with an insular environment.

The archipelago is currently suffering a significant political uncertainty, directly affecting the environmental preservation and conservation of $\mathrm{FN}$ and the spinner dolphins. The increment of the tourism brings severe consequences in a limited environment such as an island, especially concerning to sewage, solid wastes, and hydric availability, as warned by Stewart (1993) about the adverse harms of coastal and sea areas with intense tourism.

Considering the above exposed in this paper, we do the following managing recommendations and suggestions, so the tourism in $\mathrm{FN}$ and the dolphin watching have a path based on sustainability:

- continuity and intensification of the joint work between research and management towards the spinner dolphins, other cetaceans, and all the archipelago biodiversity conservation;

- continuous scientific monitoring;

- improvement of the environmental and urban expansion inspection system in the island;

- regular planning and action activities of environmental education for residents and tourists, focusing on the knowledge and the precautionary principle;

- identifying and implementing humanfree priority areas for the rest and other vital activities of the spinner dolphins population;

- intensifying the educational aspect of the boat trip through specific courses to the boat crew and conductors;

- review of the legislation to identify blanks and posterior creation of a comprehensive national law of protection for all the sea mammal species occurring on Brazilian waters, identifying and minimizing disturbing action to sea mammals and making it susceptible to changes, given the mutant nature of the ecological conditions of the occupation of sea mammals;

- review the licenses of the operating vessels in $\mathrm{FN}$;

- mandatory use of propellers protectors for all the operating vessels in $\mathrm{FN}$;

- formulation of more complete norms than the current about the traffic of boats in the MPAs of $\mathrm{FN}$, minimizing the impacts on the spinner dolphins by limiting the number of daily visits, the speed of vessels, the time of stay next to group of dolphins and kinds of permitted approaching, made through a participative management with the tour operators.

Therefore, the tourism in FN must be carefully reviewed and rigid laws must be created for all of its aspects, so the environment is not negatively affected by 
human activity. A different development must be applied in FN comparing to what happened in its history focusing on a sustainable use of natural resources.

\section{ACKNOWLEDGEMENTS}

We acknowledge the Spinner Dolphin Center sponsored by Petrobras in the SocioEnvironmental Petrobras Program for the support during the research, to Fapesb for the given scholarship to the first author, and $\mathrm{CNPq}$ for the award to the second author.

\section{REFERENCES}

Administração do Distrito Estadual de Fernando de Noronha (2015) Movimentação de turistas desembarcados no Aeroporto Carlos Wilson do Arquipélago de Fernando de Noronha. Coordenadoria de Ecoturismo

Administração do Distrito Estadual de Fernando de Noronha (2016) Superintendência de turismo, meio ambiente, esporte e lazer. Reunião ordinária do Conselho de Turismo de Fernando de Noronha

Au, W. W. L., Green, M. (2000) Acoustic interaction of humpback whales and whalewatching boats. Marine Environmental Research 49: 469-481.

Australian Government (2015) Department of Environment. Whale, dolphins and porpoises. Available www.environment.gov.au/marine/marinespecies/cetaceans. Accessed in November 18, 2015

Bejder, L., Samuels, A., Whitehead, H. (2006) Decline in relative abundance of bottlenose dolphins exposed to long-term disturbance. Conservation Biology 20: 1791-1798.

Brasil. Lei Federal $n^{\circ} 6.698$, de 17 de dezembro de 2008. Declara as águas jurisdicionais marinhas brasileiras Santuário de Baleias e Golfinhos do Brasil. Available in: http://www.planalto.gov.br/ccivil_03/_Ato20072010/2008/Decreto/D6698.htm. Accessed in : August 26, 2015
Brasil. Lei Federal $n^{\circ} 7.643$, de 18 de dezembro de 1987. Proíbe a pesca de cetáceo nas águas jurisdicionais brasileiras, e dá outras providências. Available in: http://www.planalto.gov.br/ccivil_03/Leis/L7643.ht m. Accessed in: August 26, 2015

Butler, R. W. (1980) The concept of a tourist area cycle of evolution: implications for management of resources. Canadian Geographer XXIV, 1: 5-12.

Camargo, F. S., Bellini, C. (2007) Report on the collision between a spinner dolphin and a boat in the Fernando de Noronha Archipelago, Western Equatorial Atlantic, Brazil. Biota Neotropica On line Version, 7(n1) doi 10.1590/S1676-06032007000100024

Carleton, S. L., Olson, M. D. (1999) Amerigo Vespucci and the rat of Fernando de Noronha: a new genus and species of Rodentia (Muridae: Sigmodontinae) from a volcanic island off Brazil's continental shelf. American Museum Novitates 3256:1-59.

Chalcobsky B. A., Crespo, E. A., Coscarella, M. A. (2017) Whale-watching in Patagonia: What regulation scheme should be implemented when the socio-ecological system is changing? Marine Policy 75: 165-173.

Chion, C., Cantin, G., Dionne, S., Dubeau, B., Lamontagne, P., Landry, J., Marceau, D., Martins, C. C. A., Me'nard, N., Michaud, R., Parrott, L., Turgeon, S. (2013) Spatiotemporal modelling for policy analysis: Application to sustainable management of whale-watching activities. Marine Policy 38:151-162.

Constantine, R. (1999) Effects of tourism on marine mammals in New Zealand. Science for conservation 106. Department of Conservation, Wellington. $60 \mathrm{pp}$.

Cooper, C., Jackson, S. (1989) Destination life cycle: Destination life cycle - The Isle of man case study. Annals of Tourism Research 16(3): 377-398.

Cordeiro, I. D., Gomes, E. T. A. (2016) A dinâmica da produção do espaço pelo turismo em Fernando de Noronha (Pernambuco/Brasil) e suas consequências. Revista Turydes: Turismo y Desarrollo, 20. Available

http://www.eumed.net/rev/turydes/20/pernambuc o.html 
Courbis, S., Timmel, G. (2009) Effects of vessels and swimmers on behavior of Hawaiian spinner dolphins (Stenella longirostris) in Kealake'akua, Honaunau, and Kauhako bays, Hawaii. Marine Mammal Science 25 (2): 430-440.

Debbage, K. (1990) Oligopoly and the resort cycle in the Bahamas. Annals of Tourism Research 17(4): 513-527.

Delfour, F. (2007) Hawaiian spinner dolphins and the growing dolphin watching activity in Oahu. Journal of the Marine Biological Association of the United Kingdom 87: 109-112.

Distrito Estadual de Fernando De Noronha. Instrução Normativa ${ }^{\circ} \mathbf{4}$, de 28 de dezembro de 1999. Ementa: proíbe a prática de mergulho intencional como os golfinhos rotadores. Available in: www.noronha.pe.gov.br. Accessed in: August 26, 2015

Dunker, P. (2005) Valoração Econômica do turismo de observação de golfinhos em Fernando de Noronha. Monografia de Especialização em Turismo. Universidade Estadual de São Paulo, São Paulo

Elabore - Assessoria Estratégica em Meio Ambiente (2008) Relatório de Capacidade e Suporte: Estudo e Determinação em Fernando de Noronha.

Falcão, M. C. (2010) A sustentabilidade do destino turístico de Fernando de Noronha: uma análise a partir da abordagem do ciclo de vida de áreas turísticas e das dimensões da sustentabilidade. Dissertação de mestrado. Universidade Federal de Pernambuco. Centro de Ciências Sociais Aplicadas, Departamento de Ciências Administrativas. Recife. 201p.

Feitosa, M. J. S., Gómez, C. R. P. (2013) Aplicação do Tourism Ecological Footprint Method para avaliação dos Impactos Ambientais do Turismo em Ilhas: um estudo em Fernando de Noronha. Revista Brasileira de Pesquisa em Turismo 7(2); 220-238.

Filla, G. F., Monteiro-Filho, E. L. A. (2009) O Desenvolvimento do Turismo Náutico e a sua Ligação com a Observação do Boto-Cinza (Sotalia guianensis) na Região de Cananéia, Litoral Sul do Estado de São Paulo. Turismo em Análise 20: 282-301.

Frid, A., Dilll. M. (2002) Human caused disturbance stimuli as a form of predation risk. Conservation Ecology 611.
FUNATURA (Fundação Pró-Natureza)/IBAMA. (1990) Plano de Manejo do Parque Nacional Marinho de Fernando de Noronha. Brasília: Instituto Brasileiro do Meio Ambiente e Recursos Naturais Renováveis -IBAMA

Gill, J. A., Norris, K., Sutherland, W. J. (2001) Why behavioural responses may not reflect the population consequences of human disturbance. Short note. Biological Conservation 97: 265-268.

Higham, J., Bedjer, L., Williams, R. (2014) Tourism, cetaceans and sustainable development. In: __ (Orgs.) Whale-watching: sustainable tourism and ecological management. Cambridge University Press

IBAMA. Portaria $n^{\circ}$ 05, de 25 de janeiro de 1995. Considerando a necessidade de instituir normas que venham proteger a reprodução, descanso e as crias dos golfinhos Stenella longirostris, no Arquipélago de Fernando de Noronha, Resolve

IBAMA. Portaria $n^{\circ} 117$, de 26 de dezembro de 1996. Available in: http://www.icmbio.gov.br/cepsul/images/stories/le gislacao/Portaria/1996/p_ibama_117_1996_prote caocetaceos_alterada_p_ibama_24_2002.pdf. Accessed in August 26, 2015

IBAMA. (2005) Plano de Manejo da Área de Proteção Ambiental de Fernando de Noronha, Reserva Biológica Marinha do Atol das Rocas e Arquipélago de São Pedro e São Paulo. Brasília: IBAMA

ICMBio - Instituto Chico Mendes de Conservação da Biodiversidade (2011) Plano de ação nacional para a conservação dos mamíferos aquáticos pequenos cetáceos. Brasília.

IFAW. (1997) Report of the Workshop on Educational Values of Whale Watching. International Fund for Animal Welfare. Province Town, Massachusetts

IFAW. (2000) Report of the Workshop on the Legal Aspects of Whale Watching. International Fund for Animal Welfare. Punta Arenas, Chile

Inman, A., Brooker, E., Dolman, S., McCann, R., Wilson, A. M. W. (2016) The use of marine wildlife-watching codes and their role in managing activities within marine protected areas in Scotland. Ocean and Coastal Management 132: 132-142. 
IWC - International Whaling Commission (1994) Report of the Forty-Fifth Annual Meeting, Appendix9. IWC Resolution on whalewatching. Report of the International Whaling Commission 44: 33 - 34.

Krieger, J. R., Chadwick, N. E. (2012) Recreational diving impacts and the use of pre-dive briefingsas a management strategy on Florida coral reefs. Journal of Coastal Conservation 17 :179-189.

Lodi, L. (1994) Ocorrências de BaleiasJubarte, Megaptera novaeangliae, no Arquipélago de Fernando de Noronha, incluindo um resumo de registros de capturas no Nordeste do Brasil. Biotemas 7: $116-123$.

Luis-Jr., O. J. (2009) Estudo de capacidade de carga e operacionalização das atividades de turismo náutico no Parque Nacional Marinho de Fernando de Noronha. Brasília: ICMBio/MMA

Lusseau, D. (2003a) Effects of tour boats on the behavior of bottlenose dolphins: using Markov Chains to model anthropogenic impacts. Conservation Biology 17 (6): 1785 1793.

Lusseau, D. (2003b) Male and female bottlenose dolphins Tursiops spp. have different strategies to avoid interactions with tour boats in Doubtful Sound, New Zealand. Marine Ecology Progress Series 257: 267 - 274.

Lusseau, D., Slooten, E., Currey, R. J. C. (2006) Unsustainable dolphin-watching tourism in Fiordland, New Zealand. Tourism in Marine Environments 3: 173-178.

Maida, M., Ferreira, B. P. (1997) Coral reefs of Brazil: an overview. Proc. Int. Coral Reef Symp. 8: 263-274.

Meissner, A. M., Christiansen, F., Martinez, E.,Pawley, M. D. M, Orams, M. B., Stockin, K. A. (2015) Behavioural effects of tourism on oceanic common dolphins, Delphinus sp., in New Zealand: the effects of Markov analysis variations and current tour operator compliance with regulations. Plos One 10(1): e0116962 doi:10.1371/journal.pone.0116962

Mello, T. J. (2014) Invasão biológica em ilhas oceânicas: o caso de Leucaena leucocephala (Leguminosae) em Fernando de Noronha. Dissertação de mestrado. Universidade de São Paulo. Instituto de Biociências, Departamento de Ecologia. São Paulo. 97p.
Melo, T. H. M, Porto M., Schiavetti, M. B. M. P., Campiolo, S., Schiavetti A. (2013) Legislação e prática para a conservação de cetáceos no Brasil com ênfase em atividades do turismo de observação. Revista de Direito Ambiental 69: $1-10$.

Miranda, E. E. (1994) The use of geoprocessing techniques for the environmental planning of the Fernando de Noronha Archipelago, Brazil. Revista Selper 10 (3-4): 60-66.

Monteiro-Filho, E. L. A., Filla, G. F., Domit, C., Oliveira, L. V. (2011) Ordem Cetacea. In: Reis, N. R., Peracchi, A. L., Pedro, W. A. , Lima, I. P. Mamíferos do Brasil. Londrina. 2 ed. 439p.

Muehe, D., Tenenbaum, D. R., Szechy, M. T. M. (1989) Tourism Versus Conservation In Fernando de Noronha Island, Brazil. In: Claudio Neves; Orville T. Magoon. (Org.). Coastlines of Brazil. New York: American Society of Civil Engineers, 0218-0229

Mustika, P. L. K., Birtles, A., Welters, R., Marsh, $H$. (2012) The economic influence of community-based dolphin watching on a local economy in a developing country: Implications for conservation. Ecological Economics 79: 11 - 20.

O'Connor S., Campbell, R., Cortez, H., Knowles, T. (2009) Whale Watching Worldwide. Tourism numbers, expenditures and expanding economic benefits. A special report from the International Fund for Animal Welfare, Yarmouth MA, USA

Orams, M. B. (2000) Tourists getting close to whales, is it what whale-watching is all about? Tourism Management 21: 561 - 569.

Pereira, A. I. A., Silva, F. J. L., Silva-Júnior, J. M. (2015) Influência dos cursos de capacitação do Projeto Golfinho Rotador na atuação profissional dos condutores de ecoturismo em Fernando de Noronha (PE): uma contribuição a sustentabilidade turística local. Revista Brasileira de Ecoturismo 8: 31 58.

Pratt, S., Suntikul, W. (2015) Can marine wildlife tourism provide an "edutaining" experience? Journal of Travel , Tourism Marketing doi: 10.1080/10548408.2015.1069778

Rodríguez, J. R. O., Parra-López, E., YanesEstévez, V. (2008) The sustainability of island destinations: Tourism area life cycle and teleological perspectives. The case of Tenerife. Tourism Management 29: 53-65. 
Romagnoli, F.C., Scabin, A., Pegas, F.V. (2011) Boto-vermelho (Inia geofrensis): espécie bandeira para promoção do Ecoturismo na Amazônia Central, Brasil. Revista Brasileira de Ecoturismo 4 (4): p. 518.

Santos-Jr, É., Pansard, K. C., Yamamoto, M. E., Chellappa, S. (2006) Comportamento do botocinza, Sotalia guianensis (Van Bénédén) (Cetacea, Delphinidae) na presença de barcos de turismo na Praia de Pipa, Rio Grande do Norte, Brasil. Revista Brasileira de Zoologia 23(3): 661-666.

Silva, M. B. L. (2013) Fernando de Noronha: cinco séculos de história. $2^{\mathrm{a}}$ edição. Editora Universitária da UFPE. Recife. 551 p. Série Cadernos Noronhenses

Silva-Jr., J. M., Silva, F. J. L., Sazima, I. (2005a) Rest, nurture, sex, release, and play: diurnal underwater behaviour of the spinner dolphin at Fernando de Noronha Archipelago, SW Atlantic. Journal of Ichthyology and Aquatic Biology 9 (4): 161-176.

Silva-Jr., J. M., Silva, F. J. L., Sazima, I. (2005b) Two Presumed Interspecific Hybrids in the Genus Stenella (Delphinidae) in the Tropical West Atlantic. Aquatic Mammals 31(4): 467-471.

Silva-Jr., J. M. (2017) Whale Watching: benefits, impacts and strategies. Revista Brasileira de Ecoturismo 10(2): 433-465.

Sironi, M., Leske, N., Rivera, S., Taboada, D., Schteinbarg, R. (2010) New regulations for sustainable whalewatching at Península Valdés, Argentina. Journal of Cetacean Research and Management, Scientific Committee 61, Whalewatching

Stamation, K. A., Croft, D. B., Shaughnessy, P. D., Waples, K. A., Briggs, S. V. (2010) Behavioral responses of humpback whales (Megaptera novaeangliae) to whale-watching vessels on the southeastern coast of Australia. Marine Mammal Science 26 (1); 98122.

Stewart, M. C. (1993) Sustainable Tourism Development and Marine'Conservation Regimes. Ocean \& Coastal Management 20: 201-217.

Thurstan, R. H., Hawkins, J. P., Neves, L., Roberts, C. M. (2012) Are marine reserves and non-consumptive activities compatible? A global analysis of marine reserve regulations. Marine Policy 36:1096 -1104.
Tischer, M. C., Silva-Júnior, J. M., Silva, F. J. L. (2013) Interactions of spinner-dolphins (Stenella longirostris) (Cetacea, Delphinidae) with boats at the Archipelago of Fernando de Noronha, Brazil. Pan American Journal of Aquatic Sciences 8(4): 339 - 346.

Tischer, M. C., De Carli, R. C., Silva, F. J. L. \& Silva-Jr, J. M. (2017) Tourism growth altering spinner dolphins' area of occupation in Fernando de Noronha Archipelago, Brazil. Latin American Journal of Aquatic Research 45(4):807-813.

Tolledo, J., Toledo, L. F. (2015) Blind toads in paradise: the cascading effect of vision loss on a tropical archipelago. Journal of Zoology 296: 67-176.

Tyne, J. A., Johnston, D. W., Rankin, R., Loneragan, N. R., Bejder, L. (2015) The importance of spinner dolphin (Stenella longirostris) resting habitat: implications for management. Journal of Applied Ecology doi: 10.1111/1365-2664.12434

United Nations Educational, Scientific and Cultural Organizations - UNESCO (2001) Report of the 25th Session of the Committee. Decision Code: CONF 208 X.A. Available in: http://whc.unesco.org/archive/2001/whc-01-

conf208-24e.pdf. Acessado em: December 01, 2015

United Nations Educational, Scientific and Cultural Organizations - UNESCO (2015) Convention Concerning the Protection of the World Cultural and Natural Heritage. WHC15/39.COM/8E.Rev. Paris

Vale, T. F., Robles, R. A., Moreira, J. C. (2016) O uso de tecnologias em museus e centros de visitantes: estudo de caso do centro de visitantes do Projeto Tamar de Fernando de Noronha - PE. Applied Tourism 1(1): 97-112.

Valentine, P. S., Birtles, A., Curnock, M., Arnold, P., Dunstan, A. (2004) Getting closer to whales-passenger expectations and experiences, and the management of swim with dwarf minke whale interactions in the Great Barrier Reef. Tourism Management 25: 647-655.

Woods-Ballard, A.J., Parsons, E.C.M., Hughes, A.J., Velander, K.A., Ladle, R.J., Warburton, C.A. (2003) The Sustainability of Whale-watching in Scotland. Journal of Sustainable Tourism 11: $40-55$. 
Zhong, L., Deng, J., Xiang, B. (2008) Tourism development and the tourism area life-cycle model: A case study of Zhangjiajie National Forest Park, China. Tourism Management 29 p.841

Received: 06 January 2018

Accepted: 04 April 2018

Published: 06 June 2018 